\title{
PENGARUH VARIASI DOSIS LARUTAN BUAH BELIMBING WULUH (Averrhoa bilimbi L.)TERHADAP MORTALITAS LARVA NYAMUK Culex SP. SEBAGAI SUMBER BELAJAR BIOLOGI PADA MATERI INSEKTA
}

\author{
Bagas Rasid Sidik \\ Program Magister Pendid ikan Biologi Universitas Muhammadiyah Metro \\ E-mail: Bagasrasid50@gmail.com
}

\begin{abstract}
Control of larvae of Culex sp. can be done with larvicides. Larvicides used in an attempt to reduce the population of larvae in a breeding place or for termination of the chain of mosquito breeding. Insect repellent effective to kill mosquitoes, but that has not been come mosquito larvae will develop into mosquitoes. Insect repellent made from synthetic chemicals if used excessively will cause adverse effects to humans such as respiratory disorders, digestive, and the environment. The purpose of this study was to determine (1) Whether or not the effect of giving a solution of fruit starfruit (Averrhoa bilimbi, L.) against Culex sp. mosquito larvae mortality, (2) determine the most appropriate dosage on mortality of larvae of mosquito Culex sp., (3) Compile the results of the research as a high school biology class X LKPS semester two. This study uses the method of experiment, the draft design used was completely randomized design Variety (CRD) with the control (PO) and 4 treatments, namely P1: a dose ofl/99 ml, P2: dose2/98 $\mathrm{ml}$, P3: dose $3 / 97 \mathrm{ml}$, and P4: a dose $4 / 96 \mathrm{ml}$ with 6 replicates each, the number of larvae 150 animals. Larva l sampling and testing conducted at Flores Street No. 19 Ganjar Supreme 14/2 City Metro. The test was analyzed using one-way Anava nonparametric Kruskall-Wallis test. The results of the analysis are obtained as follows: (1) There is a very significant influence on the administration of a solution of fruit starfruit (Averrhoa bilimbi, L.) against Culex mosquito larvae mortality due to the $\alpha$ sp 0.05, at a 0.01 in Chi-square table, (2) the mortality of larvae of Culex for 24 consecutive hour sare from lowest to highest mortality percentage is $P 0=0 \%$, $P 1=60 \%, P 2=83.33 \%, 83.33 \%=P 3$, andP4=86,66\%. Based on the results of research and discussion we concluded that: (1) There is the effect of star fruit solution on mortality of larvae of Culex sp mosquitoes, with coefficient $H=17.73>$ Chi-square value of7.81at $\alpha$ level of 0.05, 11, 3 Dapaalevelof 0.01., (2) At a dose of4/96 $\mathrm{ml}$ solution starfruit is the best dosage on mortality of larvae of mosquito Culex sp., (3) the results of this studying the form of LKPS (Practical Guidelines Worksheet) can support (KI) and (KD) in the curriculum syllabus 2013.
\end{abstract}

Kata Kunci: Variasi dosis, larutan belimbing wuluh, Mortalitas, larva nyamuk Culex sp., sumber belajar biologi.

\begin{abstract}
Indonesia merupakan negara tropis yang mempunyai tingkat keanekaragaman yang tinggi mulai dari segi jenis tumbuhannya, hewan dan mikrobanya, baik itu yang menguntungkan maupun yang merugikan bagi manusia. Salah satu conto hhewan yang merugikan bagi manusia adalah serangga yang dapat menjadi vector utama bagi penyebaran penyakit
\end{abstract}

berbahaya. Tusukan nyamuk Culex sp. dapat menyebabkan penyakit filariasis atau yang sering disebut dengan kaki gajah, penyakit yang disebabkan oleh cacing mikrofilaria.

Kurangnya kesadaran masyarakat dalam menangani masalah kebersihan lingkungan, menjadi sarana untuk banyaknya organisme merugikan yang timbul khususnya larva nyamuk Culex sp. 
yang terdapat di saluran-saluran yang kotor seperti kolam yang keruh, selokan, dan genangan air yang kualitas airnya kotor. Masyarakat telah banyak menggunakan cara untuk mengendalikan larva nyamuk, antara lain dengan cara kimia (pemberian larvasida pada tempattempat penampungan air), cara mekanik (menutup tempat-tempat penampungan air), dan pengendalian hayati/biologi (memelihara ikan pemakan jentik). Pengendalian vektor dari nyamuk terdiri dari beberapa langkah. Langkah awal dengan menurunkan populasi nyamuk, dengan memberantas tempat perindukan nyamuk dan juga aktivitas untuk membunuh nyamuk dewasa atau pun larva nyamuk dengan insektisida dan mencegah gigitan nyamuk agar terhindar dari penyakit-penyakit yang disebabkan oleh gigitan nyamuk (Komariah dkk, 2010)

Pengendalian yang dapat dilakukan terhadap larva Culex sp. yaitu dengan larvasida. Larvasida digunakan dalam upaya untuk mengurangi populasi jentik di suatu breeding pleace (tempat perindukan) atau untuk pemutusan mata rantai perkembangbiakan nyamuk. Larvasida paling banyak digunakan karena dapat menekan populasi larva dalam waktu singkat. Mayoritas masyarakat menggunakan obat nyamuk untuk membunuh nyamuk, obat nyamuk tersebut banyak jenisnya, yaitu obat nyamuk bakar, semprot dan elektrik. Obat nyamuk tersebut efektif untuk membunuh nyamuk, tetapi larva yang belum menjadi nyamuk akan berkembang menjadi nyamuk. Obat nyamuk yang terbuat dari bahan-bahan kimia sintetik jika digunakan secara berlebihan akan menyebabkan efek samping bagi manusia seperti gangguan pernapasan dan pencernaan (Valiant dkk, 2010).

Dalam penelitian ini peneliti mencoba untuk memberikan terobosan terbaru untuk mendapatkan insektisida nabati atau larvasida nabati yang terbuat dari bahan alami tidak membahayakan bagi manusia, tetapi dapat mengurangi populasi nyamuk. Untuk mengatasi hal tersebut peneliti mengunakan buah belimbing wuluh (Averrhoa bilimbi, L.) untuk membunuh larva nyamuk Culex sp. Peneliti menggunakan buah belimbing wuluh karena buah tersebut tersebar luas hampir di seluruh wilayah Indonesia dan pemanfaatanya di masyarakat itu sendiri minim. Buah belimbing wuluh mengandung saponin, saponin merupakan golongan senyawa triterpennoid yang dapat digunakan sebagai larvasida (Mawuntyas \& Tjandra, 2006). Hal ini sesuai dengan pendapat Aylien dkk (2012:4), bahwa pada saponin masuknya zat toksik ini ke dalam tubuh larva adalah melalui saluran pencernaan.

Pada saluran pencernaan zat toksik ini menurunkan aktivitas enzim pencernaan dan mengganggu proses penyerapan makanan sehingga saponin berfungsi sebagai racun perut. Zat toksik yang berperan dalam mematikan larva adalah alkaloid, saponin, dan flavonoid. Alkaloid yang masuk ke dalam tubuh larva melalui absorbsi dan mendegradasi membran sel kulit. Selain itu alkaloid juga dapat mengganggu sistem kerja saraf larva.Penelitimencobauntuk memvariasika ndosismana yang paling efektifuntuk membunuh larva nyamuk Culex sp.

\section{METODE}

Pada penelitian ini, peneliti menggunakan metode eksperimen yaitu memberikan perlakuan dan pengamatan terhadap mortalitas larva nyamuk Culex sp. dengan memberikan variasi dosis buah belimbing wuluh. Penelitian yang dilakukan menggunakan Rancangan Acak Lengkap (RAL). Penelitian dengan 5 perlakuan dosis dan 1 kontrol, setiap perlakuan dilakukan pengulangan sebanyak tiga kali. Kontrol adalah (tanpadosis buah belimbing wuluh), perlakuan pertama dengan pemberian 
dosis buah belimbing wuluh konsentrasi $1 \mathrm{ml} / 99 \mathrm{ml}$, perlakuan kedua dengan pemberian dosis buah belimbing wuluh konsentrasi $2 \mathrm{ml} / 98 \mathrm{ml}$, perlakuan ketiga dengan pemberian dosis buah belimbing wuluh konsentrasi $3 \mathrm{ml} / 97 \mathrm{ml}$, perlakuan keempat dengan pemberian dosis buah belimbing wuluh konsentrasi $4 \mathrm{ml} / 96 \mathrm{ml}$. Perlakuan dosis ini berdasarkan penelitian yang telah dilakukan sebelumnya dan juga uji pendahuluan yang dilakukan oleh peneliti. Hal yang diamati dalam perlakuan ini adalah laju mortalitas larva (jam) dan jumlah mortalitas larva Culex sp. pada tiap perlakuan. Sehingga perolehan data berdasarkan pada jumlah larva yang mengalami kematian pada interval waktu tertentu.

Tabel 1. Rancangan percobaan

\begin{tabular}{|c|c|c|c|c|c|}
\hline $\mathrm{U}^{\mathrm{P}}$ & $\mathrm{P}$ & $\begin{array}{c}\mathrm{P} 1 \\
(1 \%)\end{array}$ & $\begin{array}{c}\mathrm{P} 2 \\
(2 \%)\end{array}$ & $\begin{array}{c}\mathrm{P} 3 \\
(3 \%)\end{array}$ & $\begin{array}{c}\mathrm{P} 4 \\
(4 \%)\end{array}$ \\
\hline $\mathrm{U} 1$ & 5 & 5 & 5 & 5 & 5 \\
\hline $\mathrm{U} 2$ & 5 & 5 & 5 & 5 & 5 \\
\hline $\mathrm{U} 3$ & 5 & 5 & 5 & 5 & 5 \\
\hline U4 & 5 & 5 & 5 & 5 & 5 \\
\hline U5 & 5 & 5 & 5 & 5 & 5 \\
\hline U6 & 5 & 5 & 5 & 5 & 5 \\
\hline
\end{tabular}

Keterangan :

$\mathrm{P}$ : Tidak diberi perlakuan apapun (kontrol)

P1 : Pemberian dosis larutan buah belimbing wuluh $1,0 \%$

P2 : Pemberian dosis larutan buah belimbing wuluh $2,0 \%$

P3 : Pemberian dosis larutan buah belimbing wuluh $3,0 \%$

P4 : Pemberian dosis larutan buah belimbing wuluh $4,0 \%$

U1 : Ulangan satu

U2 : Ulangan dua

U3 : Ulangan tiga

U4 : Ulangan empat

U5 : Ulangan lima

U6 : Ulangan enam

5 : Jumlah banyaknya larva
Di dalam buah belimbing wuluh (Averrhoa bilimbi,L.) terdapat kandungan senyawa saponin yang merupakan golongan triterpenoid. Dimana senyawa saponin ini memiliki keistimewaan yaitu pada konsentrasi tinggi senyawa saponin dapat menyebabkan kerusakan pada sistem pencernaan karena sebagai racun perut. Dosis yang diberikan akan memiliki kemampuan yang berbeda dalam membunuh larva nyamuk Culex sp. Menurut pendapat peneliti, dengan dosis 4,0 $\mathrm{ml} / 96 \mathrm{ml}$ berpengaruh terbaik dalam mortalitas hama larva nyamuk Culex sp. karena pada buah belimbing wuluh dengan dosis tersebut banyak mengandung zat saponin yang berfungsi sebagai zat aktif bagi pengendalian larva nyamuk Culex sp. Semakin tinggi dosis larutan yang di pakai, maka semakin tinggi pula angka kematian pada larva nyamuk Culex sp. Berdasarkan kerangka berpikir tersebut, maka peneliti membuat bagan alir kerangka berpikir yang bertujuan untuk mempermudah pemahaman terhadap metodologi penelitian yang dilakukan oleh peneliti dalam menguji pengaruh variasidosis buah belimbing wuluh terhadap mortalitas larva nyamuk Culex sp. 


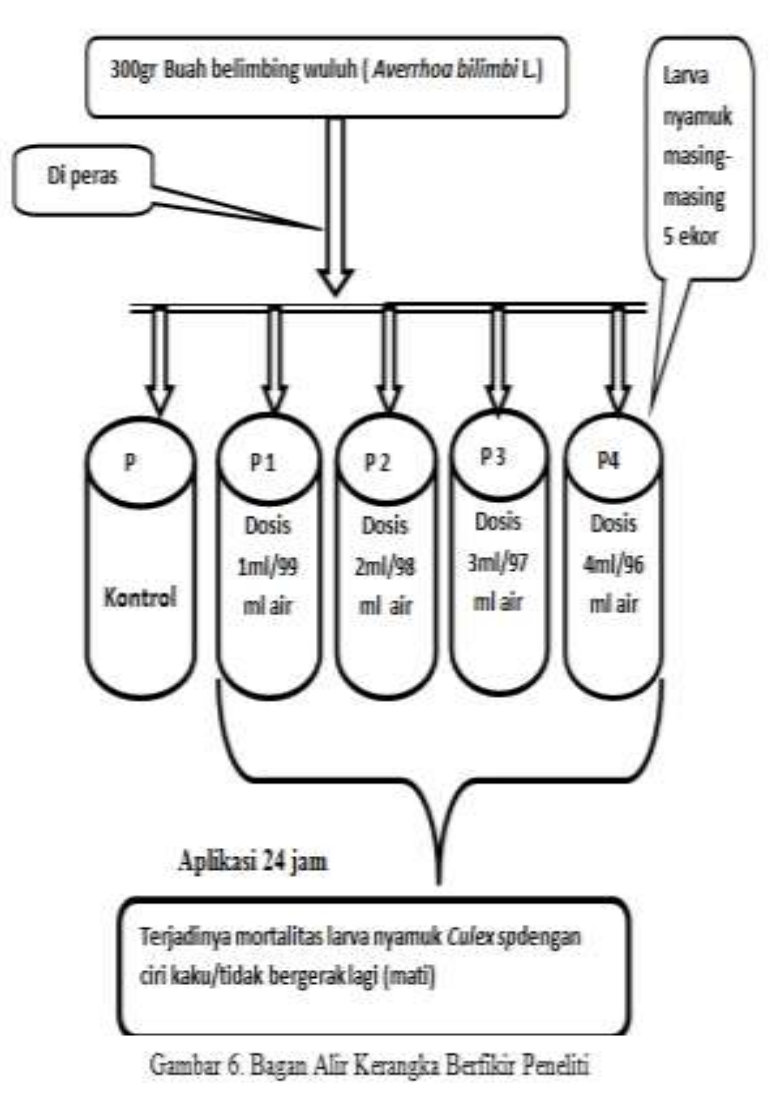

HASIL

Tabel 7. Persentase Mortalitas Larva Nyamuk Culex sp. Setelah 24

\begin{tabular}{l|l|l|l|l|l}
\multicolumn{5}{l}{ jam } \\
\hline \multirow{2}{*}{ Ulangan } & \multicolumn{4}{l}{ Perlakuan } \\
\cline { 2 - 6 } & Kontrol & $1 \%$ & $2 \%$ & $3 \%$ & $4 \%$ \\
\hline 1 & 0 & 3 & 4 & 3 & 3 \\
\hline 2 & 0 & 2 & 4 & 3 & 4 \\
\hline 3 & 0 & 4 & 3 & 5 & 5 \\
\hline 4 & 0 & 2 & 5 & 4 & 4 \\
\hline 5 & 0 & 3 & 4 & 5 & 5 \\
\hline 6 & 0 & 4 & 5 & 5 & 5 \\
\hline Jumlah & 0 & 18 & 25 & 25 & 26 \\
\hline$\%$ & $0 \%$ & $60 \%$ & $83,33 \%$ & $83,33 \%$ & $86,66 \%$ \\
\hline Kematian & $0 \%$
\end{tabular}

Berdasarkan Tabel 7 di atas, untuk mempermudah memahaminya dan membacanya dapat dilihat pada Gambar 12.

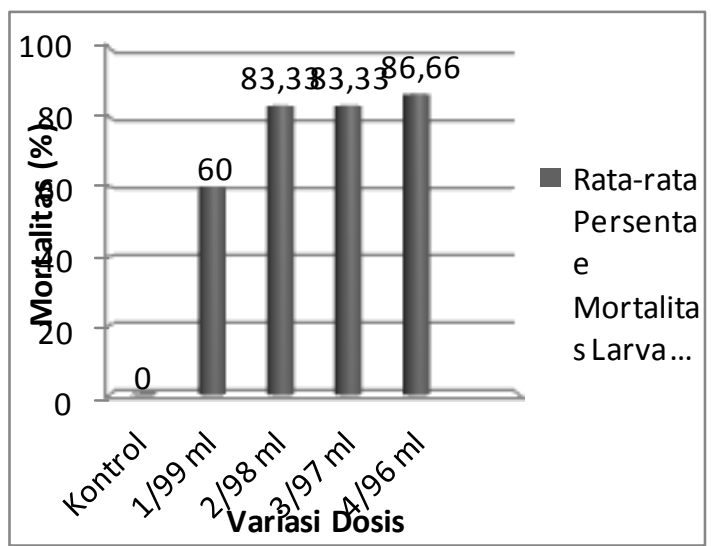

Gambar 12. Diagram Rata-rata Mortalitas Larva Culex sp. Setelah 24 Jam dalam 1 Kali Pengamatan dengan 1 Kontrol dan 4 Perlakuan.

Berdasarkan diagram dari Gambar 12 dapat diketahui nilai rata-rata persentase mortalitas dari keempat perlakuan dosis mengalami perubahan angka persentase mortalitas dari perlakuan masing-masing dosis yang diberikan. Pada kontrol mengalami mortalitas sebanyak 0 ekor larva nyamuk dengan yang hidup 30 ekor larva nyamuk sehingga persentase mortalitasnya yaitu 0\% setelah 24 jam dalam 1 kali pengamatan dengan 6 pengulangan.

Pada perlakuan pertama dosis yaitu 1/99 ml mengalami mortalitas sebanyank 18 ekor larva nyamuk dengan yang bertahan hidup 12 ekor larva nyamuk sehingga persentase mortalitasnya yaitu $60 \%$ setelah 24 jam dalam 1 kali pengamatan dengan 6 pengulangan.

Pada perlakuan kedua dengan dosis 2/98 ml angka persentase mortalitas sebanyak yaitu $83,33 \%$ setelah 24 jam dalam 1 kali pengamatan dengan 6 pengulangan serta larva nyamuk yang mengalami mortalitas 25 ekor larva nyamuk dengan yang bertahan hidup 5 ekor larva nyamuk.

Pada perlakuan ketiga dengan dosis 3/97 ml angka persentase mortalitas sebanyak yaitu $83,33 \%$ setelah 24 jam 
dalam 1 kali pengamatan dengan 6 pengulangan serta larva nyamuk yang mengalami mortalitas 25 ekor larva nyamuk dengan yang bertahan hidup 5 ekor larva nyamuk.

Pada perlakuan keempat dengan dosis 4/96 ml angka persentase mortalitas sebanyak yaitu $86,66 \%$ setelah 24 jam dalam 1 kali pengamatan dengan 6 pengulangan serta larva nyamuk yang mengalami mortalitas 26 ekor larva nyamuk dengan yang bertahan hidup 4 ekor larva nyamuk. Sehingga dari perlakuan semua dosis yang diberikan pada larva nyamuk perlakuan dosis yang paling rendah yaitu pada dosis $1 / 99 \mathrm{ml}$ dengan angka persentase mortilitas $60 \%$ dan yang paling tinggi adalah perlakuan dosis 4/96 $\mathrm{ml}$ dengan angka persentase mortalitas $86,66 \%$.

Berdasarkan perhitungan uji Kruskal Wallis, rata-rata rangking dari setiap perlakuan adalah dihitung dengan

rumus $\sum \frac{R_{i}}{N}$ dengan hasil perolehan rangking yaitu pada perlakuan pertama dengan dosis perlakuan pertama $1 / 99 \mathrm{ml}$ yaitu 18,5. Perlakuan kedua dosis $2 / 98 \mathrm{ml}$ yaitu 11. Perlakuan ketiga dosis $3 / 97 \mathrm{ml}$ yaitu 10,83 . Perlakuan keempat dosis $4 / 96$ ml yaitu 9,66.

Tolak $\mathrm{H}_{0}$ bahwa, terdapat pengaruh jika $\chi^{2}{ }_{\text {hitung }}>\chi^{2}$ tabel, hasilnya $\chi_{\text {hitung }}^{2} 17,73>\chi^{2}$ tabel 7,81 pada $\alpha$ 0,05 dan pada $\alpha \quad 0,01$ hasilnya $\chi_{\text {hitung }}^{2} 17,73>\chi_{\text {tabel }}^{2} 11,3$ pada tabel Chi-square, dengan demikian $\mathrm{H}_{0}$ ditolak dan $\mathrm{H}_{1}$ diterima bahwa ada pengaruh sangat signifikan pada variasi dosis larutan buah belimbing wuluh (Averrhoa bilimbi, L.) terhadap mortalitas larva nyamuk Culex sp.

\section{PEMBAHASAN}

Pada pengamatan kontrol (tidak diberikan larutan buah belimbing wuluh) selama 24 jam setelah aplikasi dalam 1 kali pengamatan dengan 6 pengulangan tidak ada pengaruh pada larva nyamuk sehingga tidak ada larva nyamuk yang terlihat mengalami kejadian mortalitas dengan angka mortalitas 0\%. Larva nyamuk tetap melakukan aktivitas makan, gerakan yang aktif dan mengapung pada permukaan air. Hal ini terjadi karena larva nyamuk tidak mendapat interferensi atau tekanan pada kontrol sehingga larva nyamuk tetap hidup normal, tetap aktif bergerak, aktifitas makannya berjalan seperti biasanya. Pada kontrol tersebut tidak adanya larutan buah belimbing wuluh sehingga tidak terjadinya mortalitas yang disebabkan oleh kecepatan difusi zat toksik yang masuk kedalam sel larva nyamuk. Hal ini sesuai dengan pendapat Poedjiadi dalam (Oktavia, dkk, 2011: 3) yang menyatakan bahwa kecepatan difusi tergantung pada selisih konsentrasi zat yang terlarut selama selama proses berlangsung. Artinya apabila konsentrasi menurun, maka kecepatan difusi juga menurun dan apabila konsentrasi tidak ada maka difusi pun tidak terjadi, hal ini terjadi pada kontrol yang tidak diberikan perlakuan.

Pada perlakuan pertama dosis $1 / 99 \mathrm{ml}$ selama 24 jam setelah aplikasi dalam 1 kali pengamatan dengan 6 pengulangan, jumlah larva nyamuk dalam 1 perlakuan 30 ekor sudah mengalami mortal sebanyak 18 ekor larva yaitu $60 \%$. Ciri-ciri larva yang mortal atau mati yaitu tubuh larva tidak bergerak ketika disentuh, larva tidak melakukan gerakan naik turun bahkan mengapung, dan yang tampak jelas bahwa larva dikatakan sudah mortal yakni kepala larva hampir putus dan tubuhnya mengecil dan berwarna putih pucat. Larva yang tidak mortal masih melakukan gerakan naik turun dan masih aktif artinya jika disentuh bahkan tidak 
disentuhpun larva tersebut melakukan gerakan naik turun.

Pada pengamatan perlakuan kedua, tiga dan keempat dengan dosis $2 / 98 \mathrm{ml}$, 3/97 $\mathrm{ml}$ dan 4/96 ml selama 24 jam setelah aplikasi dalam 1 kali pengamatan dengan 6 pengulangan, larva nyamuk terlihat secara langsung oleh mata ada yang mengalami mortalitas dengan angka mortalitas masing-masing pada tiap dosis yaitu mencapai $60 \%, 83,33 \%, 83,33 \%$ dan $86,66 \%$ karena adanya tekanan dari masing-masing perlakuan. Secara prosentase tentunya ada peningkatan jumlah kematian atau mortal yang signifikan, selain itu ada penuruna aktivitas larva seperti gerakan naik turun ke permukaan yang sudah melambat, serta respon terhadap sentuhan yang sudah menurun.

Penurunan gerakan naik turun ke permukaan air, melambatnya respon ketika disentuh, serta mengurusnya tubuh larva Culex sp. tersebut bahkan terjadi mortalitas hal itu dikarenakan pengaruh senyawa alkaloid, saponin, dan flavanoid yang terdapat pada larutan buah belimbing wuluh (Averrhoa bilimbi, L.).

Mekanisme kerja saponin yaitu masuknya zat toksik ini ke dalam tubuh larva adalah melalui saluran pencernaan. Pada saluran pencernaan zat toksik ini menurunkan aktivitas enzim pencernaan dan mengganggu proses penyerapan makanan sehingga saponin berfungsi sebagai racun perut (Oktavia, dkk, 2011:4).

Pada perlakuan kontrol tidak
diberikan perlakuan larutan buah
belimbing wuluh, sehingga pada
perlakuan kontrol tidak terdapat zat
saponin, flavanoid dan alkaloid yang
dapat membunuh larva nyamuk sehingga
angka mortalitasnya 0 atau semua larva
dalam keadaan hidup seperti pada habitat
awalnya. Pada kontrol dan perlakuan dosis
sangat terlihat perbedaannya dari jumlah
mortalitas pada kontrol 0\%, pada

perlakuan satu 60\%, perlakuan dua $83,33 \%$, perlakuan tiga $83,33 \%$, perlakuan empat $86,66 \%$. Perbedaan tersebut disebabkan adanya zat toksik pada perlakuan dan pada kontrol tidak terdapat zat toksik. Pada perlakuan 1, 2,3, dan 4 dapat membunuh larva nyamuk karena didalamnya terdapat larutan buah belimbing wuluh yang memiliki zat Alkaloid, saponin dan flavanoid. Alkaloid dalam daun atau buah segar berasa pahit di lidah, alkaloid berupa garam sehingga bisa mendegradasi dinding sel masuk ke dalam dan merusak sel. Saponin merupakan golongan senyawa triterpennoid yang dapat juga digunakan sebagai insektisida. Saponin terdapat pada tanaman yang kemudian dikonsumsi serangga, mempunyai mekanisme kerja dapat menurunkan aktivitas enzim pencernaan dan penyerapan makanan, sehingga saponin bersifat sebagai racun perut. Flavanoid merupakan senyawa fenol sebagai anti mikroba, anti virus, anti jamur, dan kerja terhadap serangga (Mawuntyas \& Tjandra, 2008).

\section{KESIMPULAN DAN SARAN \\ Kesimpulan}

Berdasarkan hasil penelitian dapat disimpulkan bahwa:

1. Ada pengaruh variasi dosis insektisida nabati larutan buah belimbing wuluh (Averrhoa bilimbi, L.) terhadap mortalitas larva nyamuk Culex sp., dengan nilai koefisien $\mathrm{H}=17,73>$ nilai Chi-square 7,81 pada taraf $\alpha 0,05$ dan pada $\alpha 0,01$ hasilny $\mathrm{H}=17,73$ $>$ nilai Chi-square 11,3, ada pengaruh sangat signifikan.

2. Pada dosis $4 / 96 \mathrm{ml}$ larutan buah belimbing wuluh (Averrhoa bilimbi, L.) merupakan dosis terbaik yang memiliki pengaruh paling tinggi terhadap mortalitas larva nyamuk Culex sp. 
3. Hasil penelitian ini dapat dikembangkan sebagai sumber belajar biologi dalam bentuk lembar kegiatan panduan praktikum siswa (LKPS) dalam kajian Hewan Invertebrata Filum Arthopoda dan Peranannya dalam Kehidupan.

\section{Saran}

1. Diharapkan agar dapat menggunakan insektisida nabati sebagai repelen pembasmi larva nyamuk Culex sp. yang ramah lingkungan seperti buah belimbing wuluh (Averrhoa bilimbi, L. ) yang sudah masak dan jatuh.

2. Untuk pembuatan insektisida nabati larutan buah belimbing wuluh (Averrhoa bilimbi, L.) dapat dicoba pada larva nyamuk selain Culex sp.

3. Untuk peneliti selanjutnya hendaknya menggunakan pelarut organik misalnya metanol, aceton ataupun alkohol hendaknya cara pembuatannya dengan rotari evaporator, agar didapatkan senyawa tunggal yang bersifat toksik untuk larva Culex sp.

4. Untuk peneliti selanjutnya diharapkan dapat mengembangkan hasil penelitian dengan menerapkan sumber belajar berupa lembar kerja siswa (LKS) yang berbasis kurikulum 2013.

5. Untuk guru, hasil penelitian dapat dijadikan alternatif sumber belajar biologi kajian Hewan Invertebrata Filum Arthopoda dan Peranannya dalam Kehidupan.

6. Untuk masyarakat agar menanam belimbing wuluh di samping tanaman lain.

\section{DAFTAR RUJUKAN}

Komariah, P., \& S. Malaka. 2010. Pengendalian Vektor. Palembang: STIK Bina Husada. Vol 6. No 1.

Aylien, O., Suwondo, \& F. Elya. 2011. Efektifitas Ekstrak Buah Belimbing Wuluh (Averrhoa bilimbi L.) terhadap Mortalitas Larva Nyamuk Aedes aegypti. Pendidikan Biologi:Universitas Riau

Valiant, M., S. Soeng, \& S.Tjahjanoi. 2010. Efek Infusa Daun Pepaya (Carica papaya L.) terhadap Larva Nyamuk Culex sp. Bandung:Fakultas Kedokteran, Universitas Kristen Marantha. JKM.Vol.9, No.2

Mawuntyas, \& Tjandra. 2006. Manajemen Administrasi Rumah Sakit. Edisi Kedua. UI-Pres. Jakarta. 